\title{
THE KILL OF WILD GEESE BY THE NATIVES OF THE HUDSON-JAMES BAY REGION
}

\author{
Harold C. Hanson* and Campbell Currie
}

7 HE health and economic plight of the Indians and Eskimos in northern

North America in recent years have become matters of increasing concern to the governments of Canada and the United States. Because wildlife continues to be the basic resource affecting the general welfare of these natives, its preservation and sound management assume an importance unequalled elsewhere on the continent. In the Hudson-James Bay area, wild geese constitute a significant part of the wildlife resource. This paper attempts to appraise the importance of the goose kills to the Indians and Eskimos and to the various goose populations involved.

Most of the data were gathered by the interview method. This method of assessing kills is subject to inaccuracies because of the tendency of some natives to report their kills in round figures. Winter inventory figures of goose populations cited here also contain a margin of error. Nevertheless, as both kill and population figures were obtained in the same manner in succeeding years, they should be fairly comparable from year to year.

\section{Acknowledgements}

In 1946 and 1947 field work in the Hudson-James Bay area by the senior author was supported by the Arctic Institute of North America. Further study in the region in 1954 was made possible by the Ontario Department of Lands and Forests.

For help in gathering kill data we are indebted to Harry Lumsden of the Ontario Department of Lands and Forests, Thomas Batchelor, Jack McFie, and Andrew Gagnon of the Ontario Department of Lands and Forests. G. W. Malaher and T. Nicholl of the Manitoba Department of Mines and Natural Resources kindly made data available on the goose kills in the Shamattawa-York Factory area of Manitoba. Harry Lumsden and Dr. Graham Cooch of the Canadian Wildlife Service read the manuscript and provided helpful suggestions. Cooch also supplied estimates of the Blue-Snow Goose kills at Fort Severn and Weenusk, Ontario.

Arthur S. Hawkins and Walter Crissey of the U.S. Bureau of Sport, Fisheries and Wildlife furnished annual summaries of the January inventories of Canada Geese in the Mississippi Flyway. For data on some Indian and Eskimo populations we are obligated to Eric Acland of the Indian Affairs Branch of Canada and to B. G. Sivertz of the Canada Department of Northern Affairs and Natural Resources.

* Illinois Natural History Survey, Urbana.

$\dagger$ Ontario Department of Lands and Forests, Sioux Lookout. 




Fig. 1. Fur trading posts along the coasts of Hudson and James bays.

\section{Region of Study}

The region under discussion includes the trapping grounds of the natives whose headquarters are at coastal fur trading posts of Hudson and James bays from York Factory, Manitoba, to Cape Wolstenholme, Quebec (Fig. 1). It also includes inland portions of the western part of northern Ontario and adjacent portions of Manitoba (Fig. 2), north of the transcontinental line of the Canadian National Railway. Cree Indians hunt most of the wooded areas of Ontario and Quebec adjacent to the bays and a small number of Ojibwa Indians hunt in the southwestern part of northern Ontario and adjoining portions of Manitoba north of the C.N.R. Eskimos hunt along the eastern coast of Hudson Bay from Cape Jones northward. 


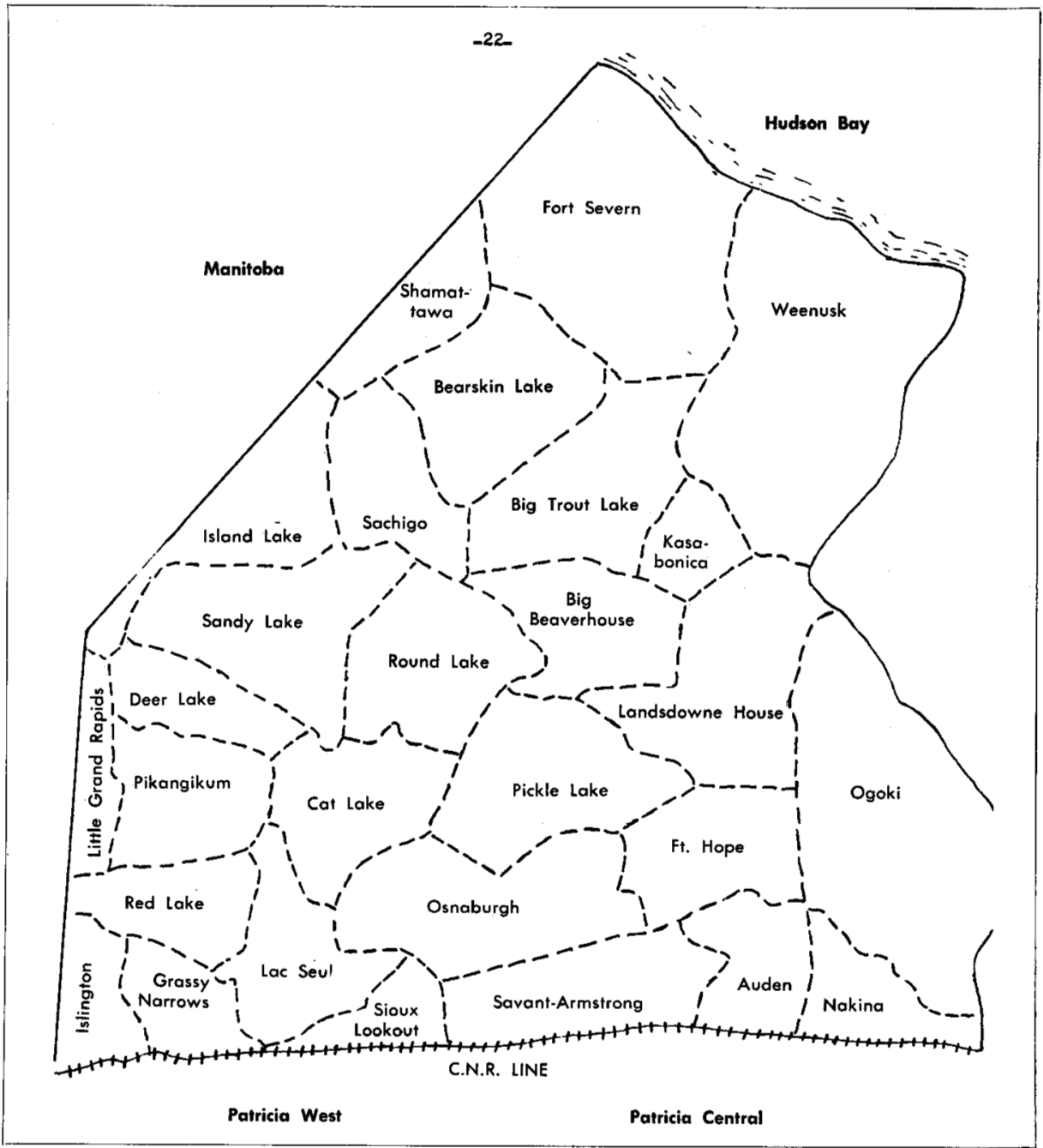

Fig. 2. Trapping areas of Indian bands residing in the central and western portions of the District of Patricia, northern Ontario. (From a map courtesy of Ontario Department of Lands and Forests).

\section{Species of geese $^{1}$}

Three species and subspecies of geese make up over 99 per cent of the goose kill in the region: Blue and Lesser Snow Geese (Anser caerulescens caerulescens) which nest on Baffin and Southampton Islands and at Eskimo Point, District of Keewatin; Canada Geese (Branta canadensis interior) of four different flyway populations which have more or less

1For the present, the writers prefer to follow the nomenclature of Delacour (1954) which was also used in an earlier paper (Hanson, Queneau, and Scott, 1956) than that of the recent American Ornithologists' Checklist (1957). 
contiguous nesting ranges around the bays (Fig. 3) (Hanson and Smith, 1950); and Richardson's Geese (Branta canadensis hutchinsii) which nest along coastal areas of Baffin and Southampton Islands and the adjacent mainland. Except for possibly a few individuals, the population of approximately 3,000 Brant (Branta bernicla hrota) which visits islands in James Bay closed to hunting (Stirrett, 1954) does not enter into the kill.

\section{Previous goose kill information}

Accurate data on the kill of geese in the North have particular significance from the management standpoint because they can usually be related to specific flyway populations. Barnston (1862) was the first to present estimates of the spring and autumn goose kills (Blue and Lesser Snow Geese) for a large part of the coastal areas of Hudson and James bays. More recent estimates of the kills of this species have been made by Stirrett (1954) and Cooch (in litt. 1955). The kills of Canada Geese were first appraised between 1945-47 by Hanson and Smith (1950) and by Hanson and Griffith (1952). The surveys in 1954, 1955, and 1956 were made to determine the kills in light of the tremendous increase of Canada Geese observed in the Mississippi Flyway since 1946.

\section{The meaning of the kill}

The meaning of the kill of a particular wildlife food resource to the native populations of the North cannot be assessed only in terms of the number of animals taken or the pounds of food furnished. Although a summary of this type is required, a subjective appraisal of the relation of particular animals - in this instance wild geese - to the morale and general welfare of the natives should also be borne in mind.

What truth there may be in the assertions that the northern natives kill large numbers of nesting geese and take their eggs must be restricted to a few bands of Eskimos, principally on the east coast of Hudson Bay, possibly the Belcher Islands, and a few sectors of Alaska. The depredations of these natives are not regarded as serious and are generally limited to the environs of native encampments (Gillham, 1948, and personal communications; Spencer, et al., 1951). Nevertheless, there may be special situations where a species should be given all the protection possible. For example, the Ross's Goose (Anser rossii) population, which breeds in the Perry River region, numbered only about 2,000 birds in 1949. The toll that the local Eskimos take of this species is believed to be small (Hanson, Queneau, and Scott, 1956), but positive steps should be taken to hold it to a minimum.

For the northern Indian, whose self-reliant mode of life has remained essentially unchanged for generations, the spring thaw and break-up of the rivers and lakes may be a time of adversity because of difficult travelling 


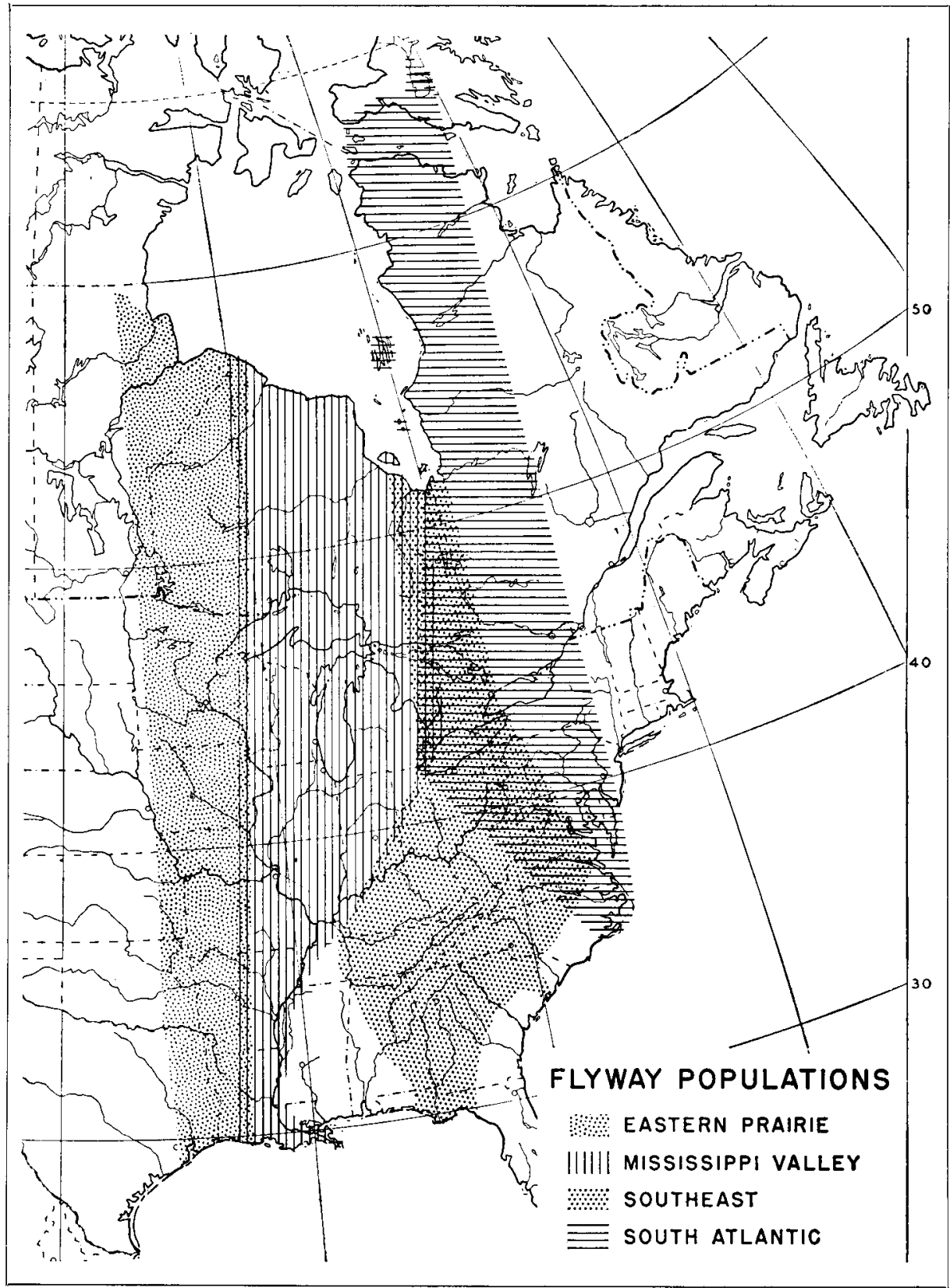

Fig. 3. The approximate ranges of four flyway populations of Canada Geese nesting in the Hudson-James Bay area. (From Hanson and Smith, 1950).

and hunting conditions. In the Hudson-James Bay region the return of Canada Geese and other waterfowl may mean a reprieve from a starvation diet, especially in years when staple food animals have undergone a cyclic decline in numbers. After months of dependence on fish and the flesh of 
furbearers, geese and other waterfowl afford a change from a monotonous diet, and possibly have unrealized nutritional values. The by-products from waterfowl, such as feathers for bedding, are also important and should not be overlooked. Thus, it is understandable that in autumn the hunts along the coasts for Blue and Snow Geese take precedence over all other activities (Fig. 4). Many of the geese shot at this time are smoked and dried or salted down for use during the winter (Fig. 5).

Similarly the Eskimos on the east coast of Hudson Bay profit when Canada Geese are available. When the conditions of the sea ice in summer create a period of adverse hunting, they turn inland for food where they make important kills of moulting, flightless Canada Geese.

One of the late Bishop Robert J. Renison's (1944, p. 105) recollections of his early days at Fort Albany is a vignette of the electrifying effect on the Indians of the return of the geese from the South. A funeral service had just been held at the small church and the mourners, cold, sick, discouraged, and hungry after a long winter, were moving on snowshoes toward the cemetery.

The Missionary walked in front, treading warily among the tents where husky dogs prowled, on his way to the little grave yard where two men with pickaxes had been for hours chipping the frozen earth deep enough to make a shallow trench. Although in the morning the whole scene looked and felt like the ragged end of winter, now the South wind grows warmer every moment and already the haze is seen in quivering waves over the melting ice and snow.

As the cortege was lost in the maze of wigwams, suddenly the cry of wild geese was heard. The funeral procession stood still and from all over the settlement came the answering call from every living soul. A great flock of Canada grey geese swept like a gigantic airplane over the trees rejoicing at what seemed a welcoming call. The phalanx turned to leeward and sailed slowly down over the spot from which the sounds came. It was too much even for sorrow and decorum. The Chief Mourner dived into his tent and appeared in a moment with his loaded gun. With incredible ease and grace he brought down a goose with each barrel. Cheers and laughter rang out. The oldest instinct of man triumphed in every simple heart and as the pallbearers patted the bereaved husband on the back, he modestly replied like a true sportsman, "She did it. I always had luck when she was with me." Then the spell was broken; the procession resumed its direction.

\section{Seasons of goose kills}

Approximately 4,600 Indians and 1,200 Eskimos reside in the trapping and hunting areas adjacent to the coasts of the bays between Churchill, Manitoba, and Wolstenholme, Quebec (Table 1). The differences in conditions of life of these people and in the terrain over which they hunt are reflected in the seasons during which the natives make their kills of geese.

The kill of Canada Geese by the Indians residing on the western side of the bays takes place about the time of break-up, which occurs from the last week in April to mid-May or late May. Indians who hunt and trap on the muskeg breeding grounds adjacent to this section of the bays normally take from 80 to 85 per cent of their annual kill in spring: Indians residing in band areas which the geese visit only during migration, that is, those areas lying south of the Fort Severn and Weenusk area (Fig. 2), take from 68 to 87 per cent of their annual kill in spring, depending on the speed of the break-up. If the break-up is rapid, the majority of the migrating flocks 
Table 1. Indian and Eskimo populations in the hunting and trapping areas adjacent to the coasts of Hudson-James Bay areas as of 1954 and 1951 respectively.

\begin{tabular}{|c|c|c|c|c|c|}
\hline Indian band 1 & Total & $\underset{16-65}{\text { Males }}$ & Eskimo band & Total & $\begin{array}{l}\text { Males } \\
16-65\end{array}$ \\
\hline Churchill & 225 & 63 & Great Whale & 142 & 39 \\
\hline York Factory & 211 & 43 & Belcher Islands & 165 & 42 \\
\hline Fort Severn & 147 & 49 & Richmond Gulf & 49 & 16 \\
\hline Weenusk & 143 & 47 & Port Harrison & 475 & 134 \\
\hline Attawapiskat & 726 & 201 & Povungnituk & 170 & 47 \\
\hline Fort Albany & 722 & 200 & Cape Smith & 127 & 36 \\
\hline Moose Factory & 570 & 153 & Wolstenholme & 103 & 35 \\
\hline Rupert House & 535 & 146 & & & \\
\hline Old Factory & 319 & 87 & & & \\
\hline East Main & 175 & 58 & & & \\
\hline Fort George & 784 & 222 & & & \\
\hline Total & $\mathbf{4 , 5 5 7}$ & 513 & & 1,231 & 349 \\
\hline
\end{tabular}

${ }^{1}$ These figures are high for some Indian posts as many families, although they continue to be registered under their original band, have moved elsewhere for employment.

pass overhead; if it is prolonged by cold and snowstorms, the flocks fly lower and make more frequent stops, thus becoming more vulnerable to the hunters.

Band recoveries demonstrate a seasonal similarity in the kill of Canada Geese by the Indians who hunt in the areas inland from the eastern coast of James Bay: about 78 per cent of their annual kill is made in the spring (Hanson and Griffith, 1952). Very few geese are taken by the Indians during the summer. The relative inaccessibility of the muskeg breeding grounds at this time would seldom make the energy expended in seeking out nesting pairs commensurate with the effort. Other types of hunting, fishing, and work about the posts usually prove to be more gainful activities.

In contrast to the Indians who make most of their kills of geese during the migration periods, the Eskimos residing along the eastern coasts of Hudson Bay obtain the largest number of Canada Geese during the summer. According to band recoveries, 64 per cent of the annual kill by these Eskimos is made during July and August, only about 11 per cent in May and June, and about 25 per cent in September and early October. Because of the absence of sea ice during the summer, these Eskimos must turn inland for a source of food. Their kill of Canada Geese at this time consists chiefly of moulting geese which are chased down on foot (Hanson and Griffith, 1952).

Richardson's Geese are shot in significant numbers by native hunters mainly in the coastal area near York Factory (Hanson, 1947; Nicholl, 1955). The Indians at this post informed the senior author in 1947 that they preferred to eat Richardson's Geese rather than Canada Geese in the fall because the former are fat when they arrive on the coast in September, whereas the resident Canada Geese are thin at that time, presumably only beginning to fatten in preparation for their fall migration. 


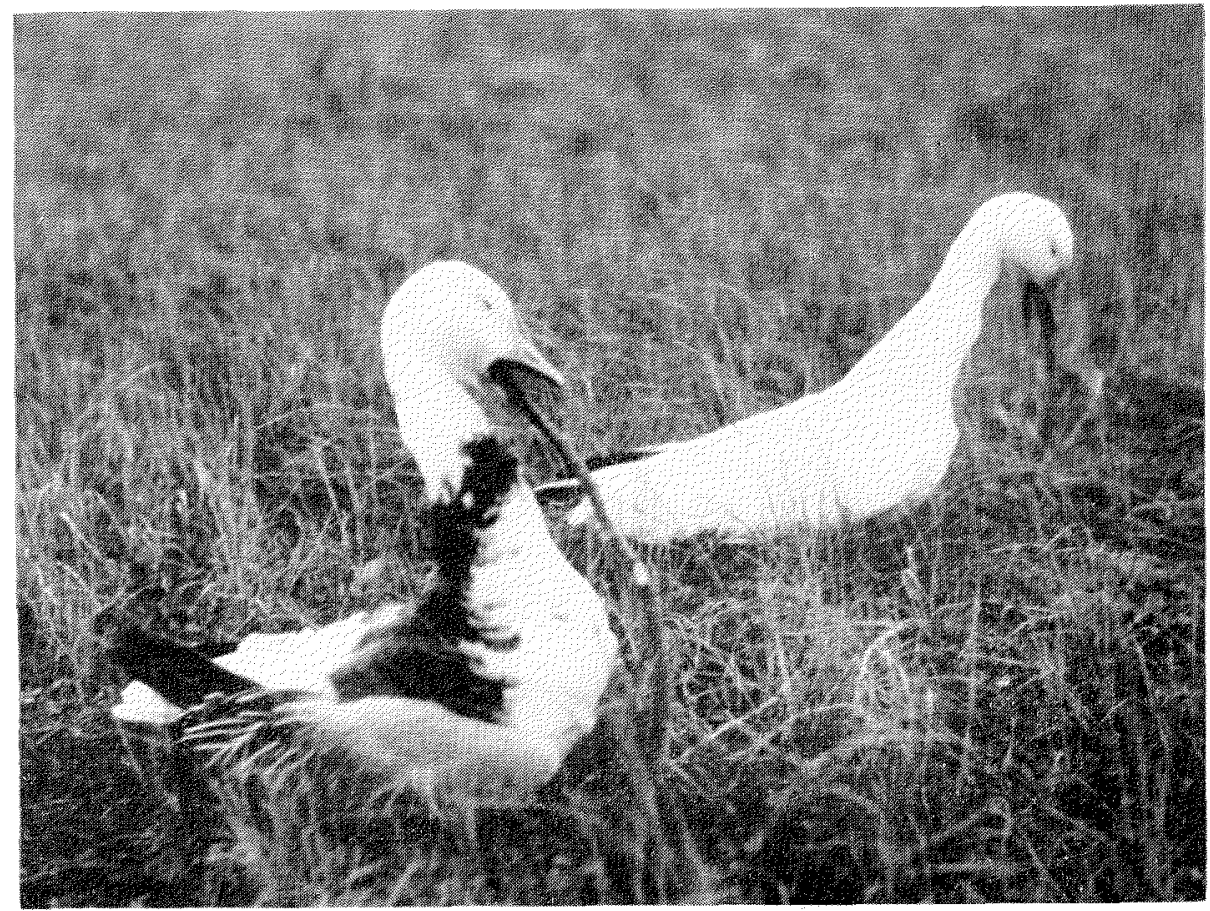

Fig. 4. Dead "waveys" propped up with a stick to serve as decoys. The goose on the left shows characteristics of both Blue and Snow colour phases. The goose on the right is a typical Lesser Snow Goose.

The kill of Snow and Blue Geese ("waveys"1) occurs along the coasts, particularly in the marshes along the southern and western coast of Hudson and James bays. The more rapid migration of these geese in spring and the presence of the Indian hunters on their inland trapping grounds at this time combine to make the spring kill of "waveys" smaller than the autumn kill. Our kill data from Fort Severn and Weenusk indicate that the spring kill of Blue and Snow Geese on the southern coast of Hudson Bay constitutes only about 6 per cent of the total annual kill of this species, while along the western coast of James Bay, at Attawapiskat, Fort Albany, and Moosonee, the kills of Snow Geese in the spring of 1956 were 36, 34, and 22 per cent, respectively, of the combined autumn 1955 and spring 1956 kills in these areas. At Attawapiskat the kill of "waveys" in the spring of 1948 was only 7 per cent of the total of the combined autumn 1947 and spring 1948 kills (report by John J. Honigmann to Indian Affairs Branch, Department of Citizenship and Immigration). According to Cooch (1956), band recoveries for the entire Hudson-James Bay region indicate that the spring kill is normally about 10 per cent of the total annual kill.

IBoth Blue and Lesser Snow Geese are called "wavy" or "wavey" which are the English equivalents of "Wa- $W \bar{a}$ ", the name used by the natives of the interior of the District of Patricia. On the coast they are called "Whăho". 


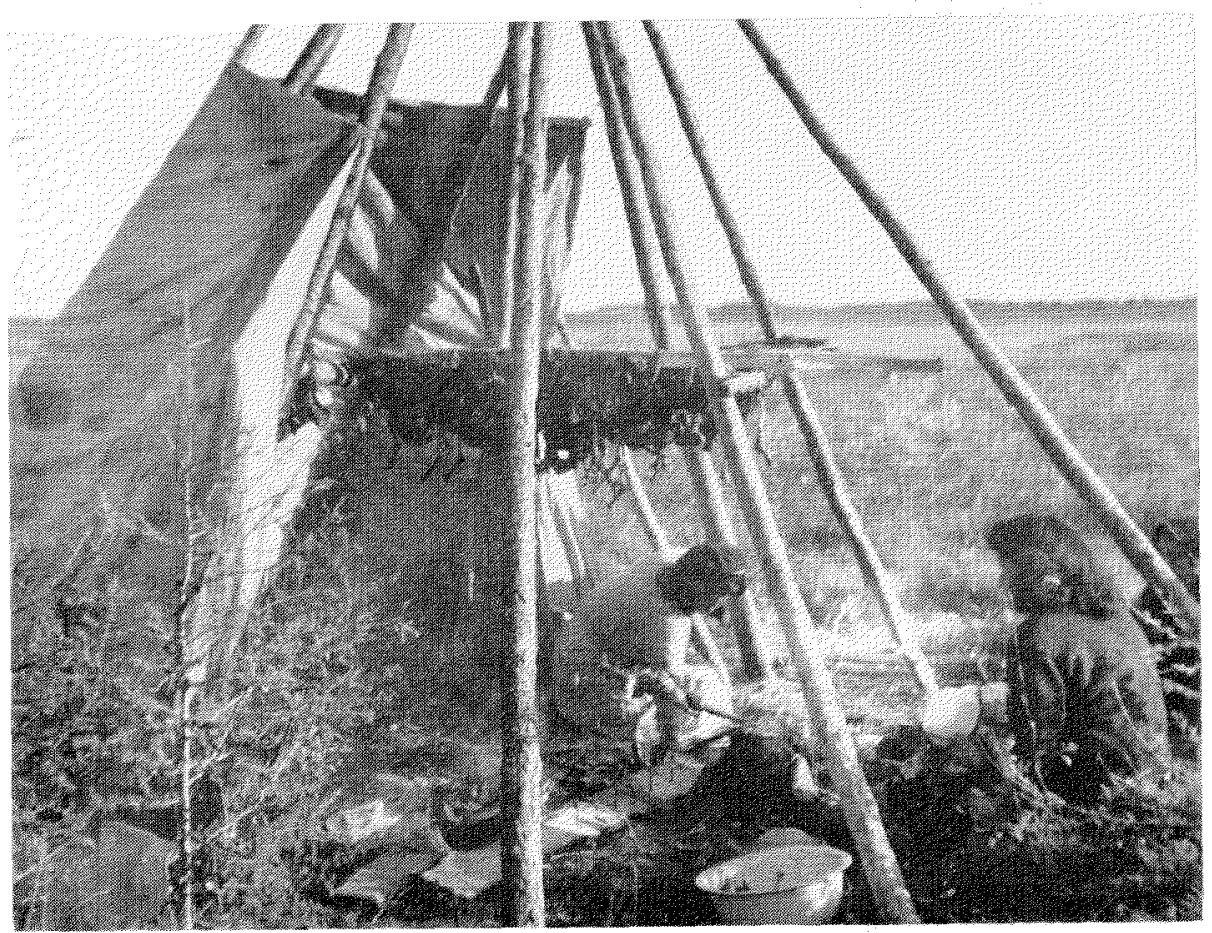

Fig. 5. Drying "waveys" as Snow Geese are called by the Indians. Such geese areutilized during the winter.

\section{Size of goose kills}

\section{Blue and Lesser Snow Geese}

Blue and Snow Geese, considered by some ornithologists to be colour phases of the same subspecies, comprise the major portion of the total goose kill by the natives of the trapping areas adjacent to Hudson and James bays. Barnston's (1862) early estimates of the annual kills for both the eastern and western coasts of the bays totaled 74,000. More recently Stirrett (1954) has placed the total annual kill at approximately 75,000 for the years 1948-53. This latter figure was based on an estimated average of nearly 100 geese per hunter for the 800 hunters residing in areas adjacent to the bays. It is difficult to fully appraise the validity of Barnston's estimate for earlier times, but the figure suggested by Stirrett (1954) for recent years is probably considerably above the upper limit of the normal range. However, conditions of native life in the North are rapidly changing in some areas with the increasing number of natives now being employed by the wood-pulp and mining industries, and on government projects. Even if not removed from their home trading post area, these Indians do relatively little hunting. The result is that a kill carefully determined for one year may not always serve as a reliable estimate for the following year. Moreover, band recoveries for only one of two years may not be an 
accurate guide to the relative size of the kill in various areas as the distribution of the Blue and Snow Geese along the Hudson Bay coast may vary from year to year. For example, in the fall of 1955 Blue and Snow Geese were scarce at York Factory and were unusually numerous at Fort Severn and Weenusk.

In 1947, 20 Indians at York Factory reported killing 300 "waveys", which is an average of 15 per hunter (Hanson, 1947). Nicholl (1955) presented figures showing that Blue and Snow Geese comprised 87 per cent of the total kill of all geese in the York Factory area in the fall of 1954, and indicated a total kill of about 1,000 birds, or 22 per hunter. Cooch (personal communication, 1955) estimated the annual kills at Fort Severn and Weenusk in 1954 to be approximately 1,500 birds per settlement. Father J. Bte. Gagnon, O.M.I., of Weenusk placed the average total "wavey" kill by the Indians of that post at 1,000 in 1947 (Hanson, 1947). Father Leopold Morin, O.M.I., estimated the annual kills in the Fort Severn region at 3,000 in 1955 . These estimates by informed observers imply an average kill of from 40 to 80 "waveys" per hunter at Fort Severn, and from 24 to 37 per hunter at Weenusk.

Dr. John J. Honigmann (1944), anthropologist in residence at Attawapiskat in 1947-8, placed the fall kill there at 5,840 and the spring kill at 440 , which was a total of 6,280 for this post. A few Indians shoot as many as 300-400; others, who must leave the coastal posts for their distant inland trapping grounds before the Blue and Snow Geese arrive, kill none. Similar circumstances are true for the Fort Albany natives. Their kill of Blue and Snow Geese in 1946-7 was estimated to be about 4,000 birds. Although the kill by some individuals may exceed 100 , it is very doubtful if the average kill per hunter for the 100 hunters of the Fort Albany band exceeded that of the Attawapiskat hunters.

Fortunately, recent and more detailed data for these latter posts and for Moosonee are now at hand. The combined autumn 1955 and spring 1956 kills of "waveys" by 80 trappers at Attawapiskat, 115 trappers at Fort Albany, and 47 trappers at Moosonee averaged 74.7, 57.9, and 15.6 birds per hunter and the total calculated kills per band area were 5,974,6,653, and 2,110 , respectively. This was a total of 14,737 for the western coast of James Bay.

Barnston's (1862) combined estimate for the kill at Fort Severn and Weenusk was 10,000 . His estimated kill of 30,000 "waveys" by the Fort Albany Indians may possibly include that of the Attawapiskat Indians as the latter are not listed by him. His figures may seem high, but in earlier times "waveys" were a year-round staple food item and an object of trade. Thousands were salted down in barrels annually and shipped to other posts.

From the data at hand it would appear that the annual fall kill of Blue and Lesser Snow Geese on the western coast of Hudson and James bays from York Factory to Fort Albany in recent years is in the neighbourhood of 20,000. Excellent "wavey" shooting is afforded the Indians who hunt in the marshes around the southern end of James Bay in autumn, but, 
in the opinion of observers familiar with this area, the average kill per Indian would not exceed that made by the Indians of more northerly groups.

There are few reliable data for the kills of "waveys" on the eastern side of Hudson and James bays, but the lack of extensive coastal marshes there make it very unlikely that the total kill of "waveys" by the Eskimo" and Indian ${ }^{2}$ hunters of the region approaches the kill made on the southern and western coasts. The restoration of beaver in the Rupert House area and subsequent trapping reduced the goose kill in that area. Prior to 1940, the Indians of the Rupert Bay area shot 1,500 to 2,000 geese in the fall, most of which were "waveys". Ten hunters there in the fall of 1943 shot 243 "waveys" but this was considered a poor hunt due to the fine weather that year (Watt, 1943). The present data, admittedly incomplete, suggest that the total "wavey" kill for all of the Hudson-James Bay region probably does not usually exceed 35,000 to 40,000 birds.

\section{Canada Geese}

To evaluate losses of Canada Geese in the Hudson-James Bay region from hunting, the kills must be related to the various flyway populations.

The Eastern Prairie Flyway population. The muskeg country of the York Factory area lies in the eastern portion of the breeding grounds of the Eastern Prairie Flyway population (Hanson and Smith, 1950). This sector of the Hudson Bay lowlands is relatively dry and contains few lakes; consequently it is much less productive of Canada Geese than the lake country south of Churchill.

Twelve hunters interviewed by Hanson in 1947 reported shooting an average of 3 Canada Geese in the fall of 1946 and an average of 4 in the spring of 1947. The largest number of geese shot by one Indian was 12; several hunters shot none. Nicholl (1955), in his study of goose kills in the York Factory area in 1954, found that Canada Geese comprised about 11 per cent of the fall kill of all species. His data indicate an average of about 2.8 Canada Geese shot per hunter. In the spring of 1955 the 45 trappers at York Factory shot an average of 13 geese, but data on the species of geese comprising this kill are not available.

The kill of Canada Geese by Indian bands is negligible (Table 2) in areas which lie to the south of the eastern portions of the breeding grounds of the Eastern Prairie Flyway population and west of longitude $90^{\circ}$, that is, the areas west of the main range of the Mississippi Flyway population (Fig. 3). The Indians of these areas reported that they see few Canada Geese in migration, and those that are observed usually pass overhead at high elevation, seldom alighting. This scarcity of migrating flocks, in addition to the few recoveries of banded geese, is considered evidence that the main pathway of migration of the Eastern Prairie Flyway population which farther south migrates through central Missouri - is farther west in Manitoba.

1349 Eskimos 16-65 years of age, 1951 census (total active hunters somewhat less). 2576 Indians 16-65 years of age, 1954 census (total active hunters somewhat less). 
Table 2. Number of Indian trappers and number of Canada Geese killed per trapper and total calculated kill in some Indian band trapping areas within the range of the Eastern Prairie Flyway Canada Goose population in western Ontario and eastern Manitoba, 1954-55.

\begin{tabular}{|c|c|c|c|c|c|c|c|c|}
\hline Band area & $\underset{1955}{\text { In }}$ & $\begin{array}{l}\text { Numb } \\
\text { and } \\
1956\end{array}$ & $\begin{array}{c}\text { trappe } \\
\text { Per } \\
\text { inte } \\
1955\end{array}$ & $\begin{array}{l}\text { at } \\
\text { ewed } \\
1956\end{array}$ & \multicolumn{2}{|c|}{$\begin{array}{c}\text { Average } \\
\text { annual kill } \\
\text { per trapper }\end{array}$} & \multicolumn{2}{|c|}{$\begin{array}{l}\text { Total } \\
\text { calculated }\end{array}$} \\
\hline \multicolumn{9}{|c|}{ Within breeding grounds } \\
\hline York Factory 1 & 45 & & $(100.0$ & & $7-12$ & & 428 & $(540)$ \\
\hline Shamattawa ${ }^{2}$ & 41 & & $(100.0)$ & & $1-3$ & & 100 & (125) \\
\hline Sub-total & 86 & & - & & - & & 528 & 665 \\
\hline \multicolumn{9}{|c|}{ South of breeding grounds ${ }^{s}$ (In Ontario) } \\
\hline Red Sucker Lake & 21 & - & 57 & 0 & 0.5 & - & 11 & (55) \\
\hline Island Lake & 81 & 72 & 47 & 100 & 0.1 & 0.4 & 8 & 29 \\
\hline Sandy Lake & 94 & 66 & 39 & 64 & 0.03 & 3.5 & 3 & 329 \\
\hline Deer Lake, Ont. & 31 & 33 & 68 & 33 & 0.2 & 1.3 & 6 & 43 \\
\hline Little Grand Rapids & 31 & 32 & 26 & 0 & 0.0 & - & 0 & (5) \\
\hline Pikangikum & 92 & 97 & 64 & 87 & 0.1 & 0.5 & 9 & 49 \\
\hline Sub-total & 350 & & & & & & 37 & 510 \\
\hline Total & 436 & & & & & & 565 & $\mathbf{1 , 1 7 5}$ \\
\hline
\end{tabular}

1Estimates based on data from Nicholl (1955) and Hanson (1947, unpublished)

2Estimates based on data from Nicholl (1955) and from interviews with 14 trappers in 1954 and 11 trappers in 1955 made by the authors.

'Data refer only to portions of the band areas lying within Ontario.

The Mississippi Flyway population. Our data are most complete for the Canada Geese of the Mississippi Flyway. This population breeds in the muskeg country of northern Ontario from about the Lawabiskau River which flows into the southwestern portion of James Bay northward and westward to a point roughly mid-way between Fort Severn, Ontario, and York Factory, Manitoba (Fig. 3). It winters chiefly in Minnesota, Wisconsin, Michigan, eastern Iowa, Illinois, Indiana, Ohio, eastern Missouri, western Kentucky, and Tennessee. A small segment of this population, possibly a total of a few thousand birds, may winter in areas adjacent to the Mississippi River south of the Tennessee state line.

In 1944 and again in 1946 and 1947 an effort was made to ascertain the kill of these geese by the Indians in western Ontario (Table 3). From data gathered by personal interviews with Indian hunters on the breeding grounds, and by estimation from band recoveries for the remainder of the Ontario range, it was calculated that the total kill was approximately 5,500 in 1944, 3,900 in 1946, and 4,700 in 1947. These totals amounted to 8-10 per cent of the northward bound flights in those years (Hanson and Smith, 1950). Studies in 1954-56 revealed that sizeable kills of geese are made in trapping areas of Indian bands living south of the breeding grounds which had not been personally investigated. The 1947 figure, used in Table 4 for comparison with more recent data, is adjusted to about 6,300. This total is equal to about 11.4 per cent of the 1946-7 wintering population. While a number of Indians at each post who are not licensed trappers hunt geese, we believe that the recorded number of licensed trappers furnishes the best basis at the present time on which to estimate the total kills. 
Table 3. Number of active Indian trappers that resided within the approximate range in Ontario of the Canada Geese of the Mississippi Flyway, 1947-56.

\begin{tabular}{|c|c|c|c|c|c|c|c|c|}
\hline Indian band trapping areas & $1946-47^{1}$ & $\underset{1954^{2}}{\text { Numbe }}$ & $r$ in band & $1956^{2}$ & 1947 & $\begin{array}{c}\text { Per cent } i \\
1954\end{array}$ & $\begin{array}{l}\text { nterviewed } \\
\quad 1955\end{array}$ & 1956 \\
\hline \multicolumn{9}{|l|}{ Within breeding grounds } \\
\hline Fort Severn & 47 & 37 & 36 & 34 & 55 & 100 & 72 & 100 \\
\hline Weenusk & 33 & 41 & 35 & 19 & 94 & 54 & 46 & 100 \\
\hline Attawapiskat & 134 & 63 & 65 & 80 & 21 & 0 & 0 & 100 \\
\hline Sutton Lake & 4 & 5 & 5 & 5 & 0 & 100 & 0 & 100 \\
\hline Fort Albany & 100 & 98 & 85 & 115 & 67 & 0 & 42 & 100 \\
\hline Ogoki & 16 & 34 & 30 & 30 & 100 & 0 & 0 & 37 \\
\hline Sub-total & 334 & 278 & 256 & 283 & & & & \\
\hline \multicolumn{9}{|c|}{$\begin{array}{l}\text { South and west of breeding } \\
\text { grounds } \\
\text { TIER I }\end{array}$} \\
\hline Kasabonica & 29 & 33 & 34 & 36 & 0 & 70 & 79 & 83 \\
\hline Landsdowne House & 98 & 106 & 106 & 107 & 0 & 73 & 70 & 68 \\
\hline Fort Hope & 24 & 29 & 28 & 27 & 0 & 79 & 89 & 70 \\
\hline Auden & 35 & 23 & 23 & 20 & 0 & 0 & 44 & 30 \\
\hline \multicolumn{9}{|l|}{ TIER II } \\
\hline Big Trout Lake & 77 & 79 & 82 & 63 & 0 & 76 & 55 & 100 \\
\hline Big Beaver House & 46 & 52 & 49 & 44 & 0 & 79 & 86 & 91 \\
\hline Pickle Lake & 63 & 65 & 70 & 60 & 0 & 49 & 46 & 66 \\
\hline Osnaburgh & 86 & 81 & 78 & 75 & 0 & 85 & 33 & 53 \\
\hline Savant-Armstrong & 74 & 70 & 70 & 71 & 0 & 0 & 41 & 0 \\
\hline \multicolumn{9}{|l|}{ TIER III } \\
\hline Sachigo Lake & 47 & 46 & 47 & 41 & 0 & 30 & 40 & 73 \\
\hline Round Lake & 40 & 57 & 57 & 51 & 0 & 63 & 84 & 69 \\
\hline Cat Lake & 34 & 32 & 32 & 33 & 0 & 0 & 53 & 82 \\
\hline Lac Seul & 119 & 130 & 127 & 75 & 0 & 0 & 0 & 0 \\
\hline Sub-total & 819 & 842 & 847 & $\mathbf{7 4 0}$ & & & & \\
\hline Total & 1,152 & 1,120 & 1,103 & 1,023 & & & & \\
\hline
\end{tabular}

1Data from Hanson and Smith (1950).

2Number of licensed trappers.

By 1954 this flyway population had increased to about 192,000 . In 1955 the January inventory revealed that there were about 225,000 on the wintering grounds, and in 1956 the population had risen to about 240,000. Thus, over a nine-year period the population had increased by 335 per cent and, in light of this, it was desirable to attempt to determine to what extent the Indians had benefitted.

Complete data for the breeding grounds that lie within the trapping grounds of the Fort Albany and Attawapiskat Indians are not available. Hence the 1953-4 data for these areas were compiled on the basis of the per cent of change in the kills made by the Fort Severn and Weenusk Indians between 1947 and 1954. The average kill by the Indians of Fort Severn and Weenusk in the spring of 1947 was 19.0 and 15.6 geese, respectively, per trapper, but the total kills for these areas when combined showed no significant variations from the 1947 and 1954 kills (Table 4).

Recoveries of banded geese have indicated that the eastern to western range of the Mississippi Flyway geese in Ontario can be satisfactorily described as including that sector of the province lying between $80^{\circ}$ and $92^{\circ}$ longitude (Fig. 3). Basing our calculations on kill data (Table 4) for 
Table 4. Number of Canada Geese killed per Indian hunter and total calculated kills in various band trapping areas within the approximate range in Ontario of the Mississippi Flyway Canada Goose population 1945-56.

\begin{tabular}{|c|c|c|c|c|c|c|c|c|c|c|c|c|c|c|c|c|}
\hline \multirow[b]{2}{*}{. } & \multicolumn{6}{|c|}{ Average kill per hunter } & \multicolumn{5}{|c|}{ Average annual kill per hunter ${ }^{1}$} & \multicolumn{5}{|c|}{ Calculated annual kill per band area ${ }^{6}$} \\
\hline & $\underset{1953}{\text { Fall }}$ & Spring & $\begin{array}{l}\text { Fall } \\
1954\end{array}$ & $\underset{1955}{\text { Spring }}$ & $\begin{array}{l}\text { Fall } \\
\mathbf{1 9 5 5}\end{array}$ & $\underset{1956}{\text { Spring }}$ & 1945-6 & $1946-7^{2}$ & 1953-4 & 1954-5 & $1955-6$ & 1945-6 & 1946-7 & $1953-4$ & 1954-5 & 1955-6 \\
\hline $\begin{array}{l}\text { Within breeding grounds } \\
\text { Fort Severn } \\
\text { Weenusk } \\
\text { Sutton Lake } \\
\text { Attawapiskat } \\
\text { Fort Albany } \\
\text { Ogoki }\end{array}$ & $\begin{array}{r}3.6 \\
5.0 \\
28.0 \\
- \\
-\end{array}$ & $\begin{array}{l}15.9 \\
21.8 \\
22.0 \\
= \\
=\end{array}$ & $\begin{array}{l}2.4 \\
\frac{4.2}{二} \\
0.4\end{array}$ & $\begin{array}{l}14.8 \\
19.6 \\
\overline{13.8}\end{array}$ & $\begin{array}{l}3.5 \\
2.1 \\
2.8 \\
1.6 \\
0.0\end{array}$ & $\begin{array}{r}13.4 \\
9.0 \\
18.0 \\
10.6 \\
16.1\end{array}$ & $\begin{aligned} 14.0 \\
15.0 \\
(30) \\
13.3 \\
9.5 \\
3.0\end{aligned}$ & $\begin{array}{l}17.0 \\
19.0 \\
(30) \\
15.6 \\
11.1 \\
3.6\end{array}$ & $\begin{array}{l}19.5 \\
26.8 \\
50.0 \\
- \\
-\end{array}$ & $\begin{array}{r}17.2 \\
23.8 \\
(45) \\
(15) \\
14.2 \\
(10)\end{array}$ & $\begin{array}{l}16.9 \\
11.0 \\
(40) \\
20.8 \\
10.6 \\
16.1\end{array}$ & $\begin{array}{c}658 \\
495 \\
(120) \\
1782 \\
950 \\
48\end{array}$ & $\begin{array}{r}790 \\
627 \\
(120) \\
2090 \\
1110 \\
56\end{array}$ & $\begin{array}{r}722 \\
1161 \\
250 \\
(1170) \\
(1030) \\
(350)\end{array}$ & $\begin{array}{c}619 \\
833 \\
(225) \\
975 \\
1207 \\
300\end{array}$ & $\begin{array}{r}608 \\
3854 \\
(200) \\
1663 \\
1402 \\
483\end{array}$ \\
\hline Sub-total or average ${ }^{3}$ & 5.6 & 18.9 & 1.5 & 15.0 & 2.2 & 13.0 & 13.1 & 13.1 & 24.7 & 16.5 & 15.2 & 4053 & 4793 & $\mathbf{5 4 4 9}$ & 4159 & 4741 \\
\hline \multicolumn{17}{|c|}{$\begin{array}{l}\text { South and west of breeding grounds } \\
\text { TIER I }\end{array}$} \\
\hline $\begin{array}{l}\text { Kasabonica } \\
\text { Landsdowne House } \\
\text { Fort Hope } \\
\text { Auden }\end{array}$ & $\begin{array}{l}2.1 \\
1.2 \\
0.3 \\
-\end{array}$ & $\begin{array}{l}3.6 \\
4.3 \\
5.3 \\
-\end{array}$ & $\begin{array}{l}0.6 \\
1.7 \\
0.2 \\
0.0\end{array}$ & $\begin{array}{l}2.7 \\
2.2 \\
0.7 \\
1.7\end{array}$ & $\begin{array}{l}0.8 \\
1.2 \\
0.1 \\
1.2\end{array}$ & $\begin{array}{l}3.5 \\
4.8 \\
6.3 \\
8.7\end{array}$ & $\begin{array}{l}- \\
-\end{array}$ & 二 & $\begin{array}{c}5.7 \\
5.5 \\
5.6 \\
(5.6)\end{array}$ & $\begin{array}{l}3.1 \\
3.9 \\
0.9 \\
1.3\end{array}$ & $\begin{array}{l}4.3 \\
6.2 \\
6.4 \\
9.8\end{array}$ & 二 & E & $\begin{array}{l}188 \\
583 \\
163 \\
(129)\end{array}$ & $\begin{array}{r}105 \\
413 \\
25 \\
30\end{array}$ & $\begin{array}{l}146 \\
657 \\
179 \\
225\end{array}$ \\
\hline Sub-total or average & 1.2 & 4.4 & 1.1 & 2.0 & 1.1 & 4.9 & 一 & - & 5.6 & 3.0 & 6.0 & - & 一 & 1063 & $\mathbf{5 7 3}$ & 1207 \\
\hline $\begin{array}{l}\quad \text { TIER II } \\
\text { Bearskin Lake } \\
\text { Big Trout Lake } \\
\text { Big Beaver House } \\
\text { Pickle Lake } \\
\text { Osnaburgh } \\
\text { Savant Lake }\end{array}$ & $\begin{array}{l}\overline{-} \\
0.0 \\
0.0 \\
0.0 \\
-\end{array}$ & $\begin{array}{l}1.0 \\
1.7 \\
1.4 \\
3.8 \\
2.4 \\
-\end{array}$ & $\begin{array}{l}0.7 \\
1.1 \\
0.1 \\
0.5 \\
0.0 \\
-\end{array}$ & $\begin{array}{l}1.0 \\
1.8 \\
0.3 \\
0.4 \\
0.3 \\
-\end{array}$ & $\begin{array}{l}0.9 \\
0.6 \\
0.6 \\
0.2 \\
0.6 \\
3.0\end{array}$ & $\begin{array}{r}3.2 \\
3.5 \\
2.7 \\
4.5 \\
2.3 \\
21.2\end{array}$ & $\begin{array}{l}= \\
\bar{z}\end{array}$ & $\begin{array}{l}\bar{z} \\
\text { 二 }\end{array}$ & $\begin{array}{l}\overline{1.7} \\
1.4 \\
3.8 \\
2.4 \\
(2.3)\end{array}$ & $\begin{array}{l}\overline{2.9} \\
0.4 \\
0.9 \\
0.3 \\
0.6\end{array}$ & $\begin{array}{r}\overline{4.1} \\
3.3 \\
4.7 \\
2.8 \\
24.0\end{array}$ & $\begin{array}{l}\bar{z} \\
\bar{z} \\
\overline{-}\end{array}$ & $\begin{array}{l}= \\
\bar{z} \\
=\end{array}$ & $\begin{array}{r}44 \\
134 \\
73 \\
247 \\
224 \\
(196)\end{array}$ & $\begin{array}{r}75 \\
238 \\
20 \\
63 \\
23 \\
42\end{array}$ & $\begin{array}{l}180 \\
258 \\
162 \\
329 \\
218 \\
208\end{array}$ \\
\hline Sub-total or average & 0.0 & 2.1 & 0.5 & 0.8 & 0.6 & 3.6 & - & - & 2.1 & 1.4 & 4.3 & - & - & 918 & 461 & 1355 \\
\hline $\begin{array}{l}\quad \text { TIER III } \\
\text { Sachigo Lake } \\
\text { Round Lake } \\
\text { Cat Lake } \\
\text { Lac Seul }\end{array}$ & $\begin{array}{l}0.0 \\
=\end{array}$ & $\begin{array}{l}2.0 \\
1.7 \\
-\end{array}$ & $\begin{array}{l}\frac{0.2}{二} \\
-\end{array}$ & $\begin{array}{l}0.7 \\
- \\
=\end{array}$ & $\begin{array}{l}0.2 \\
0.0 \\
0.3 \\
-\end{array}$ & $\begin{array}{l}2.4 \\
0.7 \\
1.9 \\
\end{array}$ & E & E & $\begin{array}{c}2.0 \\
1.7 \\
(2.0) \\
(1.8)\end{array}$ & $\begin{array}{c}0.9 \\
0.3 \\
0.2 \\
(0.3)\end{array}$ & $\begin{array}{c}2.6 \\
0.7 \\
2.3 \\
(2.0)\end{array}$ & 二 & E & $\begin{array}{r}92 \\
97 \\
(64) \\
(234)\end{array}$ & $\begin{array}{c}42 \\
17 \\
6 \\
(38)\end{array}$ & $\begin{array}{r}122 \\
40 \\
74 \\
(150)\end{array}$ \\
\hline Sub-total or average & 0.0 & 1.8 & 0. 2 & 0.7 & $\mathbf{0 . 2}$ & 1.6 & 一 & - & 1.8 & 0.4 & 1.8 & - & 一 & 487 & 103 & 386 \\
\hline Remainder of Ontario 5 & & & & & & & & & & & & $(\mathbf{1 5 0 0})$ & $(\mathbf{1 5 0 0})$ & 1000 & 660 & 1200 \\
\hline Total annual kill & & & & & & & & & & & & 5553 & 6293 & 8917 & 5956 & 8889 \\
\hline
\end{tabular}

1Data in brackets are estimates based on data for the same band area in other years or from data on the average kills in other band areas in the tier for that year. They are not included in sub-total calculations of average kill. This procedure was of ten necessary to arrive at a reasonable estimate of annual kill per band area.

From Hanson and Smith (1950)

Lome of these figures are not strictly comparable because of incomplete data.

smaller number of Indians that were engaged in trapping and hunting during the 1955-6 season.

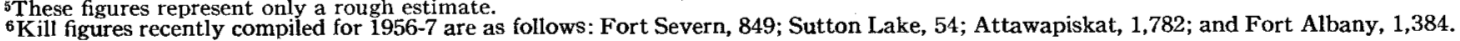


the above sector, and making allowance for the areas south of the Canadian National Railway which were not investigated, it is estimated that the total kill by the Indians in the fall of 1953 and the spring of 1954 was approximately 8,900 birds. In $1954-5$ the total kill was calculated to be about 6,000 ; in 1955-6, about 8,900. These kills were roughly $4.6,2.6$, and 3.7 per cent of the respective annual flyway populations. However, these and other losses should be added to flyway inventory figures as a part of the annual populations and the kill calculated as a percentage of the combined total for a more accurate appraisal of the Indian kill in relation to other mortality factors. This procedure would reduce the above percentages, but inclusion of an estimate for crippling would partially offset this reduction. For the purposes of this paper the calculation of the kill as a percentage of the birds assumed to have reached the North and to have been available to the natives (i.e., populations at January inventory) is considered sufficiently accurate.

From the above data it appears that the Indians' share of these geese not only did not increase in proportion to the increased goose population, but was reduced by about 65 per cent. Furthermore, the kill on the breeding grounds seems to be surprisingly stable in spite of greatly increased populations of geese. The only explanation to account for this at present is that the limited amount of time available to the Indians for hunting geese may be the main controlling factor. The critical period is limited to the time between the arrival of the geese shortly before break-up and the actual onset of break-up, an interval of two to three weeks. The largest kills by individual hunters are often made when early migrants are confined to small open areas in the rivers. When the break-up occurs, the breeding geese leave the rivers to seek nesting sites in the lake areas of the interior muskeg. In some areas of the breeding grounds these lake areas are close to the main rivers; in others, they lie several miles from the rivers. In either case the flocks become scattered and less available to hunters. Shortly after break-up the Indians leave their inland camp sites for the coastal posts.

The average spring kill per Indian in 1954 and 1956 as compared with those in 1955 for the regions lying south of the Fort Severn and Weenusk areas are strikingly dissimilar (Table 4). There are several reasons for this. In 1954 the spring was unusually late and the break-up period prolonged. Indians at both Landsdowne House and Fort Hope reported that the migrating flocks of Canada Geese were driven back south twice by late snowstorms and low temperatures before attaining their breeding grounds. A portion of the population, particularly the early migrants, possibly made as many as five flights that spring along their main migration route, thereby providing these Indians with several times their normal goose hunting opportunities. In 1955 the spring break-up was early and occurred with unusual rapidity; all of northern Ontario opened up at about the same time. As a result, most of the migrating flocks passed rapidly over the band areas south of the breeding grounds without stopping and 
thus afforded little opportunity for shooting. In 1956 the break-up was late again, resulting in another increased goose kill.

In Table 4, the kill data for the various band trapping areas indicate that the heaviest flights of northward-bound geese (exclusive of those over the actual breeding grounds) pass over the Fort Hope, Landsdowne, and Kasabanica band areas; west of these areas the frequency of migrating flocks gradually decreases. The relative scarcity of migrating flocks passing over the band trapping areas of Patricia West and adjacent areas in eastern Manitoba was further confirmed by interviews with natives of these areas in September 1954. The Fort Hope-Kasabanica flight route, which extends directly northward, apparently is used by the bulk of the geese that nest in the large breeding grounds south of Weenusk - perhaps one of the most important production centers of the Canada Geese of the Mississippi Flyway.

The South Atlantic Flyway population. Our scanty knowledge of kills of Canada Geese on the east side of Hudson and James bays, the breeding grounds of this population, has been summarized by Hanson and Griffith (1950). According to informed local observers the total kill by the 181 Eskimo hunters in the Povungnituk-Port Harrison area in the north Hudson Bay sector of the breeding range may be as high as 3,000 birds. The Rupert House Indians, as expected from band recoveries, kill few Canada Geese. Father Damase Couture reported (Hanson, 1946, unpublished) that 30 Canada Geese were the largest single kill in 1946, and that normally a kill of 10 was unusual. He stated that the kill in autumn is about nil. Studies by Mr. A. J. Kerr, who was a resident anthropologist at Rupert House in 1947, revealed a kill of 420 Canada Geese by 111 Indian hunters, or an average of 3.8 geese per hunter (Hanson and Griffith, 1952).

The kill in the intervening region is a matter of conjecture. In the James Bay sector the kill of Canada Geese is said to take place mostly north of Old Factory River. Fort George, with a large Indian population, is a major hiatus in our data (Tables 1 and 5). Band recoveries from Canada Geese banded at the Jack Miner Migratory Wildfowl Sanctuary near Kingsville, Ontario, shed some light on the relative size of the kill in different areas (Table 5). Seventy per cent of the recoveries are from the Hudson Bay sector and only 27 per cent are from the James Bay sector. Fifty-two per cent of all the recoveries were made in the area extending from the Kikkerteluk River north to Povungnituk Bay. The Eskimos who traded at the posts of Port Harrison and Povungnituk hunt this region of Hudson Bay. Assuming that the estimated kill of 3,000 geese by these natives is valid (it may be high), it would appear from band recoveries that the total kill for the entire east coast of the two bays is in the neighbourhood of 6,000 birds. This estimate necessarily rests on another assumption - that the efficiency of reporting band recoveries from the Indians of the James Bay sector and the Eskimos of the Hudson Bay sector has been approximately equal. A calculated kill of 6,000 does not appear to be an 
Table 5. Number of recoveries of Canada Geese banded at the Jack Miner Migratory Wildfowl Sanctuary, Kingsville, Ontario, 1925-44, and received from various areas of the east coasts of Hudson and James bays.

\begin{tabular}{|c|c|c|c|c|}
\hline \multirow[b]{2}{*}{ Area } & \multicolumn{2}{|c|}{$\begin{array}{l}\text { Number of } \\
\text { recoveries }\end{array}$} & \multirow[t]{2}{*}{$\begin{array}{l}\text { Total number } \\
\text { recovered }\end{array}$} & \multirow{2}{*}{$\begin{array}{c}\text { Per cent } \\
\text { of } \\
\text { total }\end{array}$} \\
\hline & $\begin{array}{l}\text { Banded } \\
\text { In spring }\end{array}$ & $\begin{array}{l}\text { Banded } \\
\text { in fall }\end{array}$ & & \\
\hline \multicolumn{5}{|l|}{ James Bay } \\
\hline Rupert House & 5 & 0 & 5 & less \\
\hline East Main & 71 & 4 & 75 & 10.8 \\
\hline Old Factory & 19 & 4 & 23 & 3.3 \\
\hline Fort George & 70 & 21 & 91 & 13.1 \\
\hline Sub-total & 165 & 29 & 194 & 27.2 \\
\hline \multicolumn{5}{|l|}{ Hudson Bay } \\
\hline $\begin{array}{l}\text { Cape Jones to Nastapoka Sound, including } \\
\text { the Belcher Islands }\end{array}$ & 101 & 26 & 127 & 18.2 \\
\hline Kikkerteluk River to Povungnituk Bay & 233 & 126 & 359 & 51.6 \\
\hline Cape Dufferin & 1 & 6 & 7 & less .1 \\
\hline Cape Smith & 6 & 2 & 8 & less \\
\hline Sub-total & 341 & 160 & 501 & 69.8 \\
\hline Total & 506 & 189 & 695 & 100.0 \\
\hline
\end{tabular}

unreasonable one; in terms of average kill per potential hunter (men from 16 to 65 years of age), it amounts to only 8.6 geese per Eskimo and 6.0 geese per Indian.

\section{Richardson's Goose}

This small subspecies of the Canada Goose is shot in appreciable numbers in the Hudson Bay area only in the vicinity of York Factory, Manitoba. In 1947, 16 Indian hunters at York Factory reported to the senior author that they killed 332 Richardson's Geese, or about 21 birds per hunter, in the fall of 1946; in the spring of 1947 they killed about 256, or an average of 16 per hunter. The Census of Indians in Canada for 1949 indicates that there were about 40 prospective hunters in the band, that is, men in the age bracket of 16-65. The total calculated kills from these data amount to 840 and 640 , respectively. Even when we assume a large margin of error, a total kill of only about 30 Richardson's Geese by these Indians in the fall of 1954 (as derived from data reported by Mr. T. Nicholl (1955) ) is startingly small. Perhaps a partial explanation of the small 1954 kill lies in Mr. Nicholl's statement that, as a result of strong west and northwest winds that fall, the migrating flocks arrived at the coast of Hudson Bay east of Cape Tatman, which is beyond the usual fall goose hunting range of the York Factory Indians. The primary reason for a reduced kill in 1954 may have been due to a smaller population of Richardson's Geese that year as evidenced by a sharp decline in the numbers which have migrated in spring through the Sand Lake National Wildlife Refuge, South Dakota, since 1952 (Harvey K. Nelson, in litt. July 31, 1957). This decline is presumably associated at least in part with the relatively heavy kills of this species that have taken place in South Dakota in recent years. 


\section{Conclusions}

Of the three kinds of geese considered here, the Blue and Snow Geese make the greatest contribution to the welfare of the natives. Kills made by Indians and Eskimos are such a small part of the total numbers of these geese (well under 5 per cent if related to the total Blue and Snow Goose population wintering in Louisiana and Texas) that they cannot be considered an important factor affecting population trends of the species. The Blue and Snow Geese which breed on Baffin and Southampton Islands are probably different management populations as they have different migration routes and wintering grounds (Manning, 1942; Cooch, 1955); hence it is desirable that eventually the kills of these geese in the various parts of Hudson and James bays be related to the proper wintering populations.

Recent increases in the numbers of Canada Geese in the Mississippi Flyway have been of some benefit to the Indians of northern Ontario, but the importance of the Indian kill of these geese relative to their numbers decreased between 1946-7 and 1954-56. The Indian kill, not considered a major mortality factor in controlling population levels in the 1940's, is now of even less consequence to over-all population trends of these Canada Geese.

The present investigation has indicated that the kills of geese made by the native hunters in the Hudson-James Bay region are within safe limits of what the nesting populations of that area can withstand. Fortunately, because of the adherance of wild geese to definite breeding grounds, migration routes, and wintering grounds, and the fact that they can be so readily censused, few waterfowl are so easily managed. Continuing improvement and expansion of the wintering grounds have done much to increase their numbers and guarantee their future. This fact, and the remote and generally inaccessible nature of their breeding grounds, offer assurance that wild geese will continue to be an important source of food for the northern natives.

\section{References}

American Ornithologists' Union. 1957. Checklist of North American birds. Fifth Ed. Publ. by the A.O.U. 691 pp.

Barnston, George. 1862. Recollections of the swans and geese of Hudson Bay. Zoologist 20: 7831-7.

Cooch, F. G. 1955. Observations on the autumn migration of Blue geese. Wilson Bull. 67: $171-74$.

1955. Letter of December 5.

1956. In Letter of David Munro, March 20.

Delacour, Jean. 1954. The waterfowl of the world. London: Country Life Ltd. Vol. 1, $284 \mathrm{pp}$.

Gillham, C. E. 1948. Don't blame the Eskimo. Field and Stream. 51:48-9.

Hanson, H. C. 1946, 1947. Unpublished field notes.

with special reference to an Illinois flock. Ill. Nat. Hist. Surv. Bull. 25:67-210. 
Hanson, H. C., and R. E. Griffith. 1952. Notes on the South Atlantic Canada goose population. Bird-Banding. 23:1-22.

, Paul Queneau, and Peter Scott. 1956. The geography, birds, and mammals of the Perry River region. Arctic Inst. of N. Amer. Spec. Publ. No. 3. 96 pp. Honigmann, J. J. 1949. Report to Indian Affairs Branch. Ottawa: Dept. of Citizenship and Immigration.

Manning, T. H. 1942. Blue and Lesser Snow geese on Southampton and Baffin islands. Auk 59:158-75.

Nelson, H. K. 1957. Letter of July 31.

Nicholl, T. 1955. The Pas. In Proceedings of conference of conservation officers. Manitoba Dept. of Mines and Nat. Resources, pp. 50-51. (mimeo.)

Renison, R. J. 1944. The miracle of spring. In Wednesday morning. Toronto: McClelland \& Stewart. p. 105.

Spencer, D. L., U. C. Nelson, and W. A. Elkins. 1951. America's Greatest goose-brant nesting area. Sixteenth N. Amer. Wildl. Conf. Trans., Amer. Wildl. Inst., Washington, D.C., pp. 290-295.

Stirrett, G. M. 1954. Field observations on geese in James Bay, with special reference to the Blue goose. Nineteenth N. Amer. Wildl. Conf. Trans., Amer. Wildl. Inst., Washington, D.C., pp. 211-220.

Watt, J. S. 1943. Letter of December 25. 